Vol. 7 (1998): 283-296.

\title{
The functional and biological properties of whey proteins: prospects for the development of functional foods
}

\author{
Hannu Korhonen, Anne Pihlanto-Leppälä, Pirjo Rantamäki and Tuomo Tupasela \\ Agricultural Research Centre of Finland, Food Research, FIN-31600 Jokioinen, \\ Finland, e-mail: hannu.j.korhonen@mtt.fi
}

\begin{abstract}
Advances in processing technologies and the accumulation of scientific data on the functional and biological properties of whey components have contributed to the growing commercial valuation of cheese whey over the last decade. New membrane separation and chromatographic techniques have made it possible to fractionate and enrich various components of whey more efficiently than before. The specific properties of these components can now be examined in greater detail and new applications developed accordingly. The utilisation of cheese whey is evolving into a new industry producing a multitude of purified ingredients for numerous purposes. The most significant areas of R\&D related to whey proteins include functional foods, the rheological properties of foodstuffs, and biopharmaceuticals.
\end{abstract}

Key words: biopharmaceuticals, cheese whey, functional foods, whey proteins

\section{Introduction}

The consumption and manufacture of cheese is increasing worldwide at a rate of about $2 \%$ per year. As a result, the amount of cheese whey is also increasing and is now estimated to be some 130 million tonnes annually. About half of this amount is produced in Western Europe, $20 \%$ in Eastern Europe, another 20\% in North America and the remaining $10 \%$ in other parts of the world (Riedel 1994a). Earlier, the disposal of whey represented a serious environmental problem, as it contains a great deal of organic substances with a high biological oxygen demand (BOD). In fact, whey contains more than half $(6-7 \%)$ of the solids present in the original milk, including about $20 \%$ of the protein, and most of the lactose, minerals and water-soluble vitamins (Sienkiewicz and Riedel 1990, Zall 1992). In countries with a highly developed dairy or food industry, whey is increasingly being used for human consumption instead of as animal feed or being disposed as waste. Innovations in whey processing have only emerged in the past two decades, with the shift to target processing of whey. Here, lactose and proteins are the most important target components. The principal processes applied in whey 
processing today are concentration, drying, fermentation and, more recently, isolation of whey proteins by means of membrane separation and chromatographic techniques to produce individual components in their purified forms.

Clearly the potential uses of whey have not been fully realised. Apart from lactose and its derivatives, increasing attention is being paid to the exploitation of individual whey proteins and other physiologically active components contained in whey. It is expected that in the future these components will find greater use in the food industries and as raw materials in the nonfood sector, e.g. the pharmaceutical and biotechnology industries. This review deals with the recent progress made in the technologies available for isolating whey proteins, analysing the functional and biological properties of individual whey proteins, and developing innovative products based on these proteins. The results of the research work on whey proteins carried out at the Food Research Institute of the Agricultural Research Centre of Finland (MTT) over the last 10 years are also reported.

\section{Isolation and modification of whey proteins}

The proteins in whey are increasingly recognised as valuable nutrients that should not be wasted. Bovine whey contains 4-7 grams of protein per litre. The concentration of whey proteins depends on the type of whey, stage of lactation and health status of the cow, and on the processing conditions in the manufacture of cheese or casein. The protein fraction comprises a wide range of individual proteins with specific characteristics. A number of review articles and text books have been published on the functional, nutritional and biological properties of whey proteins over the past 10 years (Mulvihill and Fox 1987, Fox 1989, Kinsella and Whitehead 1989, Mulvihill and Fox 1989, de Wit 1989, Sienkiewicz and Riedel 1990,
Dybing and Smith 1991, Fox and Flynn 1992, Zadow 1992, Jost 1993, Kilara 1994, Mulvihill and Fox 1994, Riedel 1994a,b,c, Wade 1994, Korhonen 1995, Riedel 1995, Regester et al. 1996, Smithers et al. 1996, Barth and Behnke 1997, de Wit 1998). Table 1 summarises the characteristics of the major milk proteins.

Since the 1970s, several industrial-scale technologies have been developed for isolating whey proteins. The advent of membrane separation techniques, in particular, has contributed to the commercial production of whole-whey protein products, e.g. whey protein concentrates (WPC) with protein contents of $30-80 \%$. The development of industrial-scale gel filtration and ion exchange chromatography techniques has made it possible to manufacture high-quality whey protein products, referred to as whey protein isolates (WPI), with protein contents of $90-95 \%$. These technologies and processes have been reviewed in several articles (Marshall and Harper 1988, Morr 1989, Hobman 1992, Jelen 1992, Morr 1992, Mulvihill 1992, Pearce 1992, Cuperus and Nijhuis 1993, Morr and Ha 1993, Rosenberg 1995). Basic membrane separation processes, such as reverse osmosis, ultrafiltration (UF) and diafiltration, are now industrially applied to the manufacture of ordinary whey powder and WPCs. A more recent technique, nanofiltration or ultraosmosis, allows the selective separation of salts and ions from whey. This method has made it possible to utilise both the salted whey derived from the manufacture of Domiati or Fetatype cheese and the industrial whey derived from the manufacture of mineral acid coagulated casein (Abd El-Salam et al. 1991). The chemical composition and functionality of whey protein products are largely affected by the method used in the process (Mangino 1992, Mulvihill 1992, Zall 1992, Kilara 1994). Due to the inconsistent functionality of the WPCs and WPIs, they are of limited use in industry. Cheese fines (casein residues) and lipid residues often interfere with membrane separation processes and impair the functionality of whey protein products. Methods based on centrifugation, heat treatment or microfiltration (MF) have been developed to elim- 


\section{AGRICULTURAL AND FOOD SCIENCE IN FINLAND}

Vol. 7 (1998): 283-296.

Table 1. Concentration and biological functions of major milk proteins.

\begin{tabular}{|c|c|c|}
\hline Protein & $\begin{array}{l}\text { Concentration } \\
\mathrm{g} / \mathrm{l}\end{array}$ & Function \\
\hline Caseins $(\alpha, \beta$ and $\kappa)$ & 28 & $\begin{array}{l}\text { Ion carrier }\left(\mathrm{Ca}, \mathrm{PO}_{4}, \mathrm{Fe}, \mathrm{Zn}, \mathrm{Cu}\right) \text {, precursors } \\
\text { of bioactive peptides }\end{array}$ \\
\hline$\beta$-Lactoglobulin & 3.3 & $\begin{array}{l}\text { Retinol carrier, binding fatty acids, possible } \\
\text { antioxidant }\end{array}$ \\
\hline$\alpha$-Lactalbumin & 1.2 & $\begin{array}{l}\text { Lactose synthesis in mammary gland, Ca carrier, } \\
\text { immunomodulation, anticarcinogenic }\end{array}$ \\
\hline Immunoglobulins $\mathrm{A}, \mathrm{M}$ and $\mathrm{G}$ & 0.7 & Immune protection \\
\hline Glycomacropeptide & 1.2 & Antiviral, bifidogenic \\
\hline Lactoferrin & 0.1 & $\begin{array}{l}\text { Antimicrobial, antioxidative, immunomodulation, } \\
\text { iron absorption, anticarcinogenic }\end{array}$ \\
\hline Lactoperoxidase & 0.03 & Antimicrobial \\
\hline Lysozyme & 0.0004 & $\begin{array}{l}\text { Antimicrobial, synergistic effect with immuno- } \\
\text { globulins and lactoferrin }\end{array}$ \\
\hline Proteose-peptones & 1.2 & Not characterised \\
\hline
\end{tabular}

References: Korhonen (1995) and Barth and Behnke (1997)

inate this problem (Maubois et al. 1987, Morr 1989). For example, the whey can be treated before MF or UF using calcium chloride addition with subsequent $\mathrm{pH}$ adjustment and heat treatment. In our studies at MTT (Tupasela et al. 1994), this method was found to improve the MF permeate flux by $30 \%$. In UF treatment, whey clarified by the above method followed by MF gave a $20-40 \%$ better flux than whey treated by MF only.

Techniques for isolating individual whey proteins have now progressed from laboratory-scale to large-scale processing, although there is still a need to improve the purity of the commercial protein products available. Different combinations of heat precipitation and UF using selective membranes have been applied for the fractionation of $\beta$-lactoglobulin $(\beta$-lg) and $\alpha$-lactalbumin $(\alpha-$ la) in enriched or purified form (Pearce 1983, Maubois et al. 1987, Konrad and Lieske 1997, Maubois and Ollivier 1997). In this technique, $\alpha$-la undergoes isoelectric precipitation at $\mathrm{pH} 4.2$ and at $55-65 \% \mathrm{C}$ due to the dissociation of calcium ions and hydrophobic inter- actions. Other minor whey proteins also precipitate under these conditions, while $\beta$-lg remains soluble and can be separated, concentrated by membrane methods, and finally dried (Bramaud et al. 1995). Tupasela et al. (1997) studied the optimisation of centrifugal separation of $\alpha$-la and $\beta-\lg$ and observed that maximum precipitation of $\alpha$-la was achieved at a whey dry matter content of $23.3 \%$, and that the separation efficiency improved with an increase in the concentration factor for whey. In addition to selective membrane separation, ion exchange chromatography using basic silica and polystyrene anion resins has been employed successfully, e.g. by Outinen et al. (1996), for the fractionation of $\beta-\mathrm{lg}$ from whey.

There is currently considerable commercial interest in the isolation of biologically active minor proteins, such as lactoferrin (LF), lactoperoxidase (LP), immunoglobulins (Ig) and casein macropeptide (CMP). A number of pilot- or industrial-scale methods have been developed for the enrichment or isolation of these compounds over the past decade, as reviewed by Mulvihill 
and Fox (1994), de Wit and Hooydonk (1996) and Maubois and Ollivier (1997). Outinen et al. (1995) have described a method for the isolation of CMP using a strong basic anion exchange resin. Several patents have recently been published in this field; in fact, most of these proteins are already commercially available as ingredients or are contained in specific products such as infant formulas, colostral supplements, milk substitutes and toothpaste, and as preservatives of raw milk (IDF 1994, Horton 1995).

The functional properties of whey proteins can be modified or improved by a variety of chemical, physical and enzymic methods (Mulvihill and Fox 1989, Nakai and Li-Chan 1989, de Wit 1989, Mulvihill 1992). Chemically modified proteins already have some use in foods, but enzymic hydrolysis and physical modification by heat or high pressure offer a whole range of innovative possibilities for extending their use. A major application for whey protein hydrolysates today is in hypo-allergenic infant formulas (Bahna 1991, Kleinman 1992, Riedel 1994b). In these products, whey proteins are partially hydrolysed with digestive and/or microbial enzymes, sometimes followed by membrane separation to achieve a specific molecular mass distribution for the hydrolysate. In this way, the allergenicity of the proteins can be reduced significantly (Jost et al. 1991, Wahn et al. 1992, Ena et al. 1995, Chirico et al. 1997). A recent study by van Beresteijn et al. (1994) showed that the minimum molecular mass to elicit immunogenicity and allergenicity by whey protein hydrolysates is between 3000 and 5000 daltons. The optimum extent of the hydrolysis with respect to immunological properties and nutritive value is, however, not known. Further research is required on how to optimise the properties of the whey protein hydrolysates used for infant feeding. Enzymatic hydrolysis of whey proteins followed by UF of the hydrolysate can also be employed for producing and enriching bioactive peptides, as shown in our own studies at MTT (Pihlanto-Leppälä et al. 1996). Such hydrolysates could find application in functional foods and clinical formulas.

\section{Functional properties of whey proteins}

The diverse physico-chemical and functional properties of whey proteins make them highly suitable for both food and non-food purposes. As ingredients of food products, whey proteins can provide functional, nutritional or economic benefits. Potential functional benefits include emulsification and stabilisation, increased viscosity, improved appearance, taste or texture, and binding of fat or water (Jost 1993). Such properties are intrinsic and specific for individual protein components, as shown in Table 2. Among the nutritional benefits of whey proteins is their ability to lower the energy content of foods when used as fat substitutes, raise the protein level, and balance the amino acid profile (Renner 1992, Barth and Behnke 1997, de Wit 1998).

The functional properties of $\beta-\mathrm{lg}$ are dominant as far as total whey protein is concerned, because of its high concentration in whey. $\beta-\mathrm{lg}$ has good foaming, emulsification and gelation properties and the ability to bind aromatic substances due to its specific molecular structure (Table 2). The good emulsifying properties of $\alpha$-la are especially important when this fraction is used in infant formulas.

The Food Research Institute of MTT recently participated in a 3-year research project concerning the manufacture of two major whey protein-enriched fractions, i.e. $\alpha$-la and $\beta$-lg, using four different pilot-scale processes. In the course of the study, the most important functional properties of the fractions were determined. In two processes, $\alpha$-la and $\beta$-lg fractions were separated by anion exchange chromatography, and in the other two, heat aggregation at low $\mathrm{pH}$ was applied to separate the protein fractions (Outinen et al. 1996). At neutral pH, all the fractions obtained by the four methods were found to have good solubility. The $\alpha$-la fractions prepared by ion exchange methods had better emulsion stability at a low protein concentration than did the fractions obtained by heat aggregation. The ap- 
Vol. 7 (1998): 283-296.

Table 2. Functional properties of proteins in whey.

\begin{tabular}{ll}
\hline Protein & Functional properties \\
\hline$\beta$-Lactoglobulin & Good foaming, emulsifying and gelation properties, \\
& Good solubility, aroma binding ability \\
$\alpha$-Lactalbumin & Good foaming and emulsifying properties, \\
& Good solubility \\
Immunoglobulins & Good gelation properties and solubility \\
Serum albumin & Good gelation properties and solubility \\
$\kappa$-Caseinmacropeptide & Good emulsifying properties \\
Proteose peptones & Good emulsifying and foaming properties \\
Lactoferrin & Good solubility, iron binding ability \\
\hline
\end{tabular}

References: Hegg (1982), Marshall (1982), Harper (1984), Paulsson et al. (1986), de Wit et al. (1986), O'Neill and Kinsella (1987), de Wit et al. (1988)

parent viscosities were similar to those of a commercial whey protein concentrate, as reported by Tossavainen et al. (1998). The water-holding properties of the fractions were equal except for the denatured $\alpha$-la fraction obtained by heat aggregation, which had a better water-holding capacity than did the others. The heat aggregation method was the only one that preserved good foaming properties in both the $\alpha$-la and $\beta$-lg enriched fractions. All the processes tested preserved the good gelation properties of $\beta$-lg (Rantamäki et al. 1998). Both whey protein fractions were also tested in model foods, e.g. infant formulas and bakery products, to obtain information about the behaviour of the proteins in the presence of other food components (Tossavainen et al. 1998, Rantamäki et al.1998).

In addition to conventional whey and its proteins, research has also focused on bovine colostrum, and on the modification of proteins using this new resource. Bovine colostrum differs from normal milk in many respects, e.g. in the content and composition of the proteins. A major class of proteins in colostrum is represented by immunoglobulins, but their content in the colostrum of individual cows varies considerably, from 30 to 120 grams per litre (Korhonen 1977, Stott et al. 1981, Nousiainen et al. 1994). The functional properties of whey proteins and their enzymatic hydrolysates have been studied extensively, whereas there has been only limit- ed research on colostral whey proteins in this respect. In studies conducted at MTT (Korhonen et al. 1997), the functional properties of two bovine colostral whey protein concentrates and their hydrolysates, prepared by different processes, were compared with a commercial cheese whey-based protein concentrate and its hydrolysate. The emulsification, foaming properties and gelation ability were measured for both the proteins and their hydrolysates. The functional properties of two colostral WPCs were comparable to those of the commercial WPC, except for the foaming properties, which were significantly better in the colostral WPCs. Marked differences were observed when the products were hydrolysed, gelation and foaming properties being considerably improved in the colostral whey hydrolysates. We may therefore expect colostral WPCs to find various fields of application in the food industry, either as such or modified by hydrolysis.

One of the future potential applications of whey proteins is in the area of edible films and coatings (Krochta et al. 1994). These could enhance the quality of food by preventing the migration of water and lipids within food and help to improve the keeping quality of food, for instance, by preventing the rancidity of lipids (Gennadios et al. 1994, McHugh and Krochta 1994, Maté et al. 1996, Gennadios et al. 1997). Coating also replenishes the nutritional value of 
a product and lessens the need for packing material. In our preliminary studies, we prepared edible films and coatings from whey protein concentrates, isolates and $\beta$-lg, and tested the quality of the films by measuring their mechanical and physical properties such as tensile strength, puncture strength and water vapour permeability. Model foodstuffs were coated with edible film, and the effect of the coating on the structure and shelf-life of the products was studied both with instruments and by organoleptic analyses (Myllärinen et al. 1997). Further studies are in progress, focusing especially on the coating of dairy products.

The functionality of whey proteins can be retained by applying membrane techniques or chromatographic methods for their isolation or enrichment. Such functional ingredients are already widely used in bakery and confectionery products, and in dairy products such as yoghurts and various cheeses to improve their yield, nutritional value and consistency. In addition, an increasing number of dietetic beverages, weight loss diets and sports nutrition products supplemented with whey protein concentrates or specific protein fractions have been launched on US, European and Far Eastern markets (Mulvihill 1992, Riedel 1994b,c, Riedel 1995, O'Carrol 1997, Barth and Behnke 1997).

\section{Biological properties of whey proteins}

Bovine whey contains a wide range of biologically active proteins, i.e. about 60 indigenous enzymes, vitamin-binding proteins, metal-binding proteins, immunoglobulins and various growth factors and hormones. These components have been reviewed by Reiter (1985), IDF (1991, 1994), Fox and Flynn (1992), Smithers et al. (1996), Barth and Behnke (1997), Regester et al. (1997) Pakkanen and Aalto (1997), Parodi
(1998) and Xu (1998). Most of the known or putative biological activities of specific whey proteins are related to the functions of the immune or digestive system (Table 1). In recent studies, a total whey protein diet has been shown to have immunostimulatory (Bounous et al. 1989, Wong and Watson 1995) and anticarcinogenic effects in mice and rats (Bounous et al. 1988, Bounous et al. 1991, Mc Intosh et al. 1995). It has therefore been suggested that whey proteins might find use as a food supplement for immunecompromised individuals and in the prevention of diet-related cancers (Bounous et al. 1993, Parodi 1998). Further research is, however, needed to substantiate these important findings. Of particular interest at present are lactoperoxidase, lactoferrin and Igs, all of which have found commercial applications. These proteins are antimicrobial in function and are considered primary non-cellular defence factors of the body against microbial infections. Several methods have been devised and patented for isolating these antibacterial compounds from colostrum and milk. Current commercial applications include preservation of foodstuffs and animal feeds and, more interestingly, prevention and treatment of various infectious diseases in humans and domestic animals (Facon et al. 1993, Hambraeus and Lönnerdahl 1994, Stadhouders and Beumer 1994, Davidson 1996, de Wit and Hooydonk 1996). In the following, interest focuses on Igs, as they have attracted increasing commercial interest in the last few years. Bioactive peptides derived from milk proteins are also discussed in some detail. Particular reference is made to peptides released from whey proteins, since they provide a highly potential source of physiologically active components for dietary and medical purposes.

\section{Immunoglobulins and specific antibodies}

Igs are present in cow's colostrum in a 50 to 100 times higher concentration than in milk. The Igrelated antibody-complement system active in colostrum is known to confer passive immunity 
Vol. 7 (1998): 283-296.

to the neonate calf until its own immune system has matured (Butler 1994). Following this rationale, Igs have been isolated from colostrum, cheese whey and blood serum by UF for the purpose of manufacturing commercial supplements for neonatal calf, lamb or piglet feeding. The efficacy of such supplements has been variable (Mee and Mehra 1995), but those based on native colostral Igs, in particular, have proved beneficial to the health of newborn calves (Nousiainen et al. 1994). The efficacy of colostral supplements can be improved by immunising cows with specific antigens derived from pathogenic microbes. Systemic immunisation of pregnant cows during the dry period produces colostrum with high concentrations of specific antibodies against the vaccine used. The antibodies can be enriched in an active form from colostrum by membrane separation and chromatographic techniques to make specific Ig concentrates (Syväoja et al. 1994). Such immune milk preparations have been shown to be effective in the prevention or treatment of various enteric diseases in calves or piglets (Saif et al. 1983, Tsunemitsu et al. 1989, Schaller et al. 1992, Moon and Bunn 1993).

A number of clinical studies have been carried out since the 1970 s to demonstrate the efficacy of immune milk preparations in the prophylaxis or therapy of human gastrointestinal diseases. These studies have been reviewed by Reddy et al. (1988), Goldman (1989), Boesman-Finkelstein and Finkelstein (1991), Hammarström et al. (1994), Ruiz (1994), Davidson (1996) and Pakkanen and Aalto (1997). Clinical evidence obtained in most of these studies indicates that immune milk preparations are protective and, to some extent, also therapeutic against rotavirus infections in children (Ebina et al. 1985, 1992, Brüssow et al. 1987, Hilpert et al. 1987, Davidson et al. 1989, Turner and Kelsey 1993). A protective or therapeutic effect of immune milk has also been demonstrated in humans against enteropathogenic or enterotoxigenic $E$. coli infections (Mietens et al. 1979, Tacket et al. 1988) and Shigella flexneri (Tacket et al. 1992). Another clinical trial has shown that a specific immune milk product reduces the number of caries streptococci in human dental plaque (Filler et al. 1991). Highly encouraging results have been reported in a number of studies with immune bovine colostrum-containing specific antibodies to Cryptosporidium parvum (Tzipori et al. 1987, Nord et al. 1990, Plettenberg et al. 1993, Shield et al. 1993, Greenberg and Cello 1996). The patients treated were immunosuppressed due to HIV infection.

In studies with mice at MTT we have demonstrated that a colostrum-based immune milk preparation provides efficient protection against Helicobacter felis infection in mice (RehnbergLaiho et al. 1995). Preliminary clinical trials on chronic gastritis patients and children infected with Helicobacter pylori showed that treatment with an immune milk preparation containing specific Helicobacter pylori antibodies derived from colostrum of immunised cows decreased the degree of the symptoms and the rate of Helicobacter colonisation in most subjects (Korhonen et al. 1994, Oona et al. 1997). Further model studies with mice are under way to identify the potential therapeutic efficacy of the immune milk against Helicobacter infection in experimentally infected mice.

In another immune milk study, we have shown that a colostrum-based immune milk concentrate has significant antimetabolic potential against mutans streptococci (Loimaranta et al. 1997) and that such a preparation actively inhibits in vitro the adherence of these bacteria to hydroxyapatithe (Loimaranta et al. 1996). A clinical trial is in progress to demonstrate the potential efficacy of anti-caries immune milk in vivo.

A few immune milk products derived from colostrum or milk of hyperimmunised cows have been launched on the market in the US, Australia, New Zealand and Taiwan. It has been suggested that immune milk products could provide a potential alternative for, or a supplement to, antibiotics (Facon et al. 1993, Ruiz 1994). The supplementation of infant formulas with specific antibodies has also been suggested in some studies (Reddy et al. 1988, Goldman 1989, Davidson 1996). 
Seminar in honour of the 100th anniversary of MTT

Table 3. Examples of biologically functional peptides derived from bovine whey proteins.

\begin{tabular}{|c|c|c|c|c|c|}
\hline Precursor protein & Fragment & Peptide sequence & Name & Function & References \\
\hline$\alpha$-Lactalbumin & $50-53$ & Tyr-Gly-Leu-Phe & $\alpha$-Lactorphin & $\begin{array}{l}\text { Opioid agonist, } \\
\text { ACE inhibition }\end{array}$ & $\begin{array}{l}\text { Antila et al. 1991, } \\
\text { Mullally et al. } 1996\end{array}$ \\
\hline \multirow[t]{3}{*}{$\beta$-Lactoglobulin } & $102-105$ & Tyr-Leu-Leu-Phe & $\beta$-Lactorphin & $\begin{array}{l}\text { Non-opioid stimulatory } \\
\text { effect on ileum, } \\
\text { ACE inhibition }\end{array}$ & $\begin{array}{l}\text { Antila et al. 1991, } \\
\text { Mullally et al. } 1996\end{array}$ \\
\hline & $142-148$ & $\begin{array}{l}\text { Ala-Leu-Pro-Met- } \\
\text { His-Ile-Arg }\end{array}$ & - & ACE inhibition & Mullally et al. 1997 \\
\hline & $146-149$ & His-Ile-Arg-Leu & $\beta$-Lactotensin & Ileum contraction & $\begin{array}{l}\text { Pihlanto-Leppälä et al. } \\
1997\end{array}$ \\
\hline \multirow[t]{2}{*}{ Bovine serum albumin } & $399-404$ & Tyr-Gly-Phe-Gln-Asn-Ala & Serorphin & Opioid & Tani et al. 1994 \\
\hline & $208-216$ & $\begin{array}{l}\text { Ala-Leu-Lys-Ala-Trp- } \\
\text { Ser-Val-Ala-Arg }\end{array}$ & Albutensin A & $\begin{array}{l}\text { Ileum contraction, } \\
\text { ACE inhibition }\end{array}$ & Yamauchi 1992 \\
\hline Lactoferrin & $17-42$ & $\begin{array}{l}\text { Lys-Cys-Arg-Arg-Trp- } \\
\text { Glu-Trp-Arg-Met-Lys- } \\
\text { Lys-Leu-Gly-Ala-Pro- } \\
\text { Ser-Ile-Pro-Ser-Ile-Thr- } \\
\text { Cys-Val-Arg-Arg-Ala-Phe }\end{array}$ & Lactoferricin & Antimicrobial & $\begin{array}{l}\text { Dionysius and Milne } \\
1997\end{array}$ \\
\hline
\end{tabular}

\section{Bioactive peptides}

Bioactive peptides have been identified as degradation products of several food proteins. The most important sources of bioactive peptides, milk proteins, have been shown to have opiate, antithrombotic or antihypertensive activities and immunomodulating or mineral absorption properties (Chiba and Yoshikawa 1986, Yamauchi 1992, Meisel and Schlimme 1996, Meisel 1997, Xu 1998). Some of them are known to influence insulin secretion or intestinal motility and secretion (Daniel et al. 1990).

The bioactive peptides obtained from whey proteins, and their physiological effects, have been less extensively studied than have caseins (Table 3). Yoshikawa et al. (1986) first studied whey proteins in this regard. They synthesised tetrapeptides in amide form on the basis of the opioid-like fragments, Tyr- $\mathrm{X}_{1}-\mathrm{X}_{1}-\mathrm{Phe}$, contained in the primary structures of $\alpha$-la (both bovine and human) and $\beta$-lg (bovine). The fragment containing residue $50-53$ of $\alpha$-la (Tyr-Gly-LeuPhe) in amide form was referred to as $\alpha$-lactorphin. Analogously, the 102-105 amide fragment of $\beta$-lg (Tyr-Leu-Leu-Phe) was called $\beta$-lactorphin. Studies by Antila et al. (1991) showed that $\beta$ - lactorphin was released only in samples predigested with pepsin when combined with proteolysis with trypsin, trypsin and chymotrypsin, or pancreatin. $\alpha$-Lactorphin was released during proteolysis with pepsin alone. The effects of $\alpha$ and $\beta$-lactorphin on guinea pig ileum were apparent at a concentration of $10^{-4} \mathrm{M}$, unlike morphine, which inhibited contractions at $10^{-6} \mathrm{M}$. The results indicate that $\alpha$-lactorphin exerts a naloxone-sensitive inhibition of smooth muscle contractions similar to that of morphine. In contrast, $\beta$-lactorphin induced stimulation of smooth muscle that was not sensitive to naloxone. The affinity of $\alpha$-lactorphin for opioid receptors was about 1000 -fold lower than that of morphine. Binding of $\beta$-lactorphin to the opioid receptors was similar to that of $\alpha$-lactorphin. It was concluded that $\alpha$-lactorphin exerted receptor binding and a weak but consistent opioid property in smooth muscle, whereas $\beta$-lactorphin, despite the similar receptor binding affinity, exerted an apparently non-opioid stimulatory effect on the guinea pig ileum (Paakkari et al. 1994).

Yamauchi (1992) has reported that peptides derived from serum albumin (SA) and $\beta$-lg induced contraction of the guinea pig ileum longitudinal muscle when the test was done without 


\section{AGRICULTURAL AND FOOD SCIENCE IN FINLAND}

Vol. 7 (1998): 283-296.

electric stimulation in the absence of an agonist. The peptides were referred to as "peptides acting on smooth muscle" and they contained SA f208-216 (albutensin A) and $\beta$-lg f146-149 ( $\beta$ lactotensin). This peptide can be released during hydrolysis with chymotrypsin. In our pharmacological studies of $\beta$-lactotensin, morphine inhibited the contractions of the coaxially stimulated guinea pig ileum at concentrations of $10^{-8}-10^{-5} \mathrm{M}$. The effect of $\beta$-lactotensin was the opposite of that of morphine, which was used as a reference. Moreover, the opioid antagonist naloxone $\left(10^{-6} \mathrm{M}\right)$ did not inhibit the effect of $\beta$ lactotensin (Pihlanto-Leppälä et al. 1997). The stimulatory effect of $\beta$-lactotensin on smooth muscle was similar to that of $\beta$-lactorphin. The results indicate that the contracting effect of $\beta$ lactotensin and $\beta$-lactorphin on smooth muscle was not mediated by an opioid mechanism, and the effect thus remains unclear.

Whey peptides have also been found to have angiotensin converting enzyme (ACE)-inhibitory activity. The ACE is part of the rennin-angiotensin system, which has been implicated in blood pressure regulation and hypertension. Rennin acts on the angiotensinogen and releases a largely inactive angiotensin, I, which is then converted to the active peptide hormone, angiotensin II, by ACE. The tetrapeptides, $\alpha$-lactorphin, $\beta$ lactorphin and $\beta$-lactotensin, and related peptides have been shown to have ACE-inhibitory activity (Mullally et al. 1996). The lactorphins appear to have multifunctional activities similar to those of several casein-derived peptides, e.g. casomorphin-7 (Meisel and Schlimme 1994). Chiba and Yoshikawa (1991) have characterised a multifunctional bioactive peptide, albutensin A, serum albumin f208-216. The $\beta$-lg peptide obtained after tryptic digestion of $\beta$-lg and identified as $\beta$-lg f142-146 has been the most active ACEinhibitory whey peptide reported to date (Mullally et al. 1997). In our studies at MTT we have shown that hydrolysis of whey proteins by different proteolytic enzymes produces ACE-inhibitory activity, and have identified several ACEinhibitory peptides from whey proteins (Pihlanto-Leppälä et al. 1998). Our findings indicate that

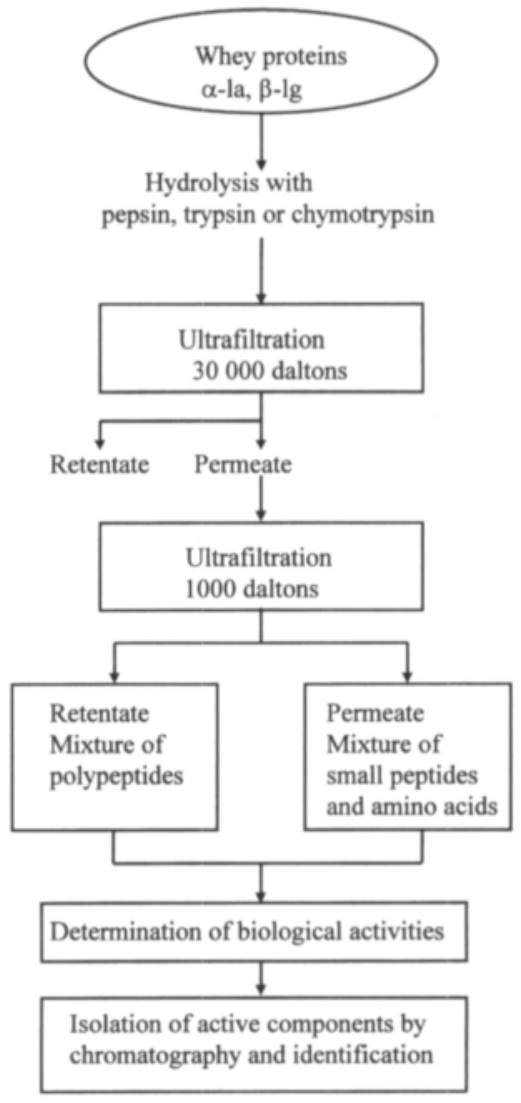

Fig. 1. Processing scheme for production and separation of bioactive peptides from whey proteins obtained by enzymatic hydrolysis.

whey proteins also have ACE-inhibitory activity, but that more research is needed to show the activity of these peptides/hydrolysates in animals.

Peptides with biological activity can be produced in several ways. The most common methods are the processing of foods using hot alkali or acid to hydrolyse proteins, enzymatic hydrolysis of food proteins, and/or microbial fermentation. Enzymatic hydrolysis combined with a two-step UF technique can be used to selectively enrich the bioactive peptides in hydrolysates, as shown in Fig. 1 (Pihlanto-Leppälä et al. 1996). 


\section{References}

Abd El-Salam, M.H., El-Shibiny, S., Mahfouz, M.B., ElDein, H.F., El-Atriby, H.M. \& Antila, V. 1991. Preparation of whey protein concentrate from salted whey and its use in yogurt. Journal of Dairy Research 58: 503-510.

Antila, P., Paakkari, I., Järvinen, A., Mattila, M.J., Laukkanen, M., Pihlanto-Leppälä, A., Mäntsälä, P. \& Hellman, J. 1991. Opioid peptides derived from in vitro proteolysis of bovine whey proteins. International Dairy Journal 1: 215-229.

Bahna, S.L. 1991. Breast milk and special formulas in prevention of milk allergy. Advances in Experimental Medicine and Biology 310: 445-451.

Barth, C.A. \& Behnke, U. 1997. Ernährungsphysiologische Bedeutung von Molke und Molkenbestandteilen. Nahrung 41: 2-12.

Beresteijn, E.C.H. van, Peeters, R.A., Kaper, J., Meijer, R.J.G.M., Robben, A.J.P.M. \& Schmidt, D.G. 1994. Molecular mass distribution, immunological properties and nutritive value of whey protein hydrolysates. Journal of Food Protection 57: 619-625.

Boesman-Finkelstein, M. \& Finkelstein, R.A. 1991. Bovine lactogenic immunity against pediatric enteropathogens. In: Mestecky, J. et al. (eds.). Immunology of milk and the neonate. Plenum Publishing Corp., New York. p. 361-367.

Bounous, G., Baruchel, S., Falutz, J. \& Gold, P. 1993. Whey proteins as a food supplement in HIV-seropositive individuals. Clinical and Investigative Medicine 16: 204-209.

- , Batist, G. \& Gold, P. 1989. Immunoenhancing property of dietary whey protein in mice: Role of glutathione. Clinical and Investigative Medicine 12: 154161.

- Batist, G. \& Gold, P. 1991. Whey proteins in cancer prevention. Cancer Letters 57: 91-94.

Bramaud, C., Aimar, P. \& Daufin G. 1995. Thermal isoelectric precipitation of $\alpha$-lactalbumin from whey protein concentrate: Influence of protein-calcium complexation. Biotechnology and Bioengineering 47: 121-130.

Brüssow, H., Hilpert, H., Walther, J., Sidoti, J., Mietens, C. \& Bachmann, P. 1987. Bovine milk immunoglobulins for passive immunity to infantile rotavirus gastroenteritis. Journal of Microbiology 25: 982-986.

Butler, J.E. 1994. Passive immunity and immunoglobulin diversity. Proceedings of the IDF seminar "Indigenous antimicrobial agents of milk - Recent developments". IDF Special Issue 9404: 14-50.

Chiba, H. \& Yoshikawa, M. 1986. Biologically functional peptides from food proteins: New Opioid peptides from milk proteins. In: Feeney, R.E. \& Whitaker, J.R. (eds.) Protein tailoring for food and medical uses. Marcel Dekker, New York. p. 123-153.

- \& Yoshikawa, M. 1991. Bioactive peptides derived from food proteins. Kagaku to Seibutsu 29: 454-458.

Chirico, G., Gasparoni, A., Ciardelli, L., De Amici, M., Colombo, A. \& Rondini, G. 1997. Immunogenicity and antigenicity of a partially hydrolyzed cow's milk infant formula. Allergy 52: 82-88.

Cuperus, F.P. \& Nijhuis, H.H. 1993. Applications of membrane technology to food processing. Trends in Food Science \& Technology 4: 277-282.

Daniel, H., Vohwinkel, M. \& Rehner, G. 1990. Effect of casein and $\beta$-casomorphins on gastrointestinal motility in rats. Journal of Nutrition 120: 252-257.

Davidson, G.P. 1996. Passive protection against diarrheal disease. Journal of Pediatric Gastroenterology and Nutrition 23: 207-212.

-, Whyte, P.B.D., Daniels, E., Franklin, K., Nunan, H., McCloud, P.I., Moore, A.G. \& Moore, D.J. 1989. Passive immunization of children with bovine colostrum containing antibodies to human rotavirus. Lancet ii: 709-712.

Dionysius, D.A. \& Milne, J.M. 1997. Antibacterial peptides of bovine lactoferrin: Purification and characterization. Journal of Dairy Science 80: 667-674.

Dybing, S.T. \& Smith, D.E. 1991. Relation of chemistry and processing procedures to whey protein functionality. Cultured Dairy Products Journal 26: 4-12.

Ebina, T., Ohta, M., Kanamaru, Y., Yamamaoto-Osumi, Y. \& Baba, K. 1992. Passive immunizations of suckling mice and infants with bovine colostrum containing antibodies to human rotavirus. Journal of Medical Virology 38: 117-123.

- , Sato, A., Umezu, K., Ishida, N., Ohyama, S., Oizumi, A., Aikawa, K., Katagiri, S., Katsushima, N., Imai, N., Kitaoka, S., Suzuki, H. \& Konno, T. 1985. Prevention of rotavirus infection by oral administration of cow colostrum containing anti-human rotavirus antibody. Medical Microbiology and Immunology 174: 177-185.

Ena, J.M., Beresteijn, E.C.H. van, Robben, A.J.P.M. \& Schmidt, D.G. 1995. Whey protein antigenicity reduction by fungal proteinases and a pepsin/pancreatin combination. Journal of Food Science 60, 1: 104110, 116.

Facon, M., Skura, B.J. \& Nakai, S. 1993. Potential for immunological supplementation of foods. Food and Agricultural Immunology 5: 85-91.

Filler, S.J., Gregory, R.L., Michalek, S.M., Katz, J. \& McGhee, J.R. 1991. Effect of immune bovine milk on Streptococcus mutans in human dental plaque. Archives of Oral Biology 36: 41-47.

Fox, P.F. 1989. The milk protein system. In: Fox, P.F. (ed.). Developments in dairy chemistry - 4. Elsevier Applied Science, London. p. 1-53.

- \& Flynn, A. 1992. Biological properties of milk proteins. In: Fox, P.F. (ed.). Advanced dairy chemistry, Volume 1, Proteins. Elsevier Applied Science. p. 255284.

Gennadios, A., Hanna, M.A. \& Kurth, L.B. 1997. Application of edible coatings on meats, poultry and seafoods: A review. Lebensmittel-Wissenschaft und Technologie 30: 337-350.

- , McHugh, T.H., Weller, C.L. \& Krochta, J.M. 1994. Edible coatings and films based on proteins. In: 


\section{AGRICULTURAL AND FOOD SCIENCE IN FINLAND}

Vol. 7 (1998): 283-296.

Krochta, J. et al. (eds.). Edible coatings and films to improve food quality. Technomic Publishing Co. Inc., Lancaster, Basel. p. 201-277.

Goldman, A.S. 1989. Immunologic supplementation of cow's milk formulations. Bulletin of the IDF 244: 3842.

Greenberg, P.D. \& Cello, J.P. 1996. Treatment of severe diarrhea caused by Cryptosporidium parvum with oral bovine immunoglobulin concentrate in patients with AIDS. Journal of Acquired Immune Deficiency Syndromes and Human Retrovirology 13: 348-354.

Hambraeus, L. \& Lönnerdahl, B. 1994. The physiological role of lactoferrin. Proceedings of the IDF seminar "Indigenous antimicrobial agents of milk - Recent developments". IDF Special Issue 9404: 97-107.

Hammarström, L., Gardulf, A., Hammarström, V., Janson, A., Lindberg, K. \& Smith, C.I.E. 1994. Systemic and topical immunoglobulin treatment in immunocompromised patients. Immunological Reviews No. 139. p. 43-70.

Harper, W.J. 1984. Model food system approaches for evaluating whey protein functionality. Journal of Dairy Science 67: 2745-2756.

Hegg, P.-O.1982. Conditions for the formation of heatinduced gels of some globular food proteins. Journal of Food Science 47: 1241-1244.

Hilpert, H., Brũssow, H., Mietens, C., Sidoti, J., Lerner, L. \& Werchau, H. 1987. Use of bovine milk concentrate containing antibody to rotavirus to treat rotavirus gastroenteritis in infants. Journal of Infectious Diseases 156: 158-166.

Hobman, P.G. 1992. Ultrafiltration and manufacture of whey protein concentrates. In: Zadow, J.G. (ed.). Whey and lactose processing. Elsevier Applied Science. p. 195-230.

Horton, B.S. 1995. Commercial utilization of minor milk components in the health and food industries. Journal of Dairy Science 78: 2584-2589.

IDF 1991. Significance of the indigenous antimicrobial agents of milk to the dairy industry. Bulletin of the IDF 264: 2-19.

- 1994. Proceedings of the IDF seminar "Indigenous antimicrobial agents of milk - Recent developments". Uppsala, Sweden, 31 August - 1 June 1994. IDF Special Issue 9404. 228 p.

Jelen, P. 1992. Pressure-driven membrane processes: principles and definitions. IDF Special Issue 9201 "New Applications of Membrane Processes". p. 714

Jost, R. 1993. Functional characteristics of dairy proteins. Trends in Food Science \& Technology 4: 283-288.

Jost R.J., Monti, C. \& Pahud, J.J. 1991. Reduction of whey protein allergenicity by processing. Advances in Experimental Medicine and Biology 289: 309-320.

Kilara, A. 1994. Whey protein functionality. In: Hettiarachchy, N. \& Ziegler, G.R. (eds.). Protein functionality in food systems. Marcel Dekker Inc. New York. p. 325355.

Kinsella, J.E. \& Whitehead, D.M. 1989. Proteins in whey: chemical, physical and functional properties. Advances in Food and Nutrition Research 33: 343-438.

Kleinman, R.E. 1992. Cow milk allergy in infancy and hypoallergenic formulas. Journal of Pediatrics 121: S116-S121.

Konrad, G. \& Lieske, B. 1997. Neues Verfahren zur technischen Isolierung von nativem $\beta$ - lactoglobulin aus Molke durch enzymatische Hydrolyse und Ultrafiltration. Deutsche Milchwirtschaft 48, 13: 479-482.

Korhonen, H. 1977. Antimicrobial factors in bovine coIostrum. Journal of the Scientific Agricultural Society of Finland 49: 434-447.

- 1995. Whey as raw material for development of new products for human nutrition and health: A Review. Proceedings of the NJF/NMR-seminar No. 252. Turku, Finland, 13-15.1.1995. NJF- Report 102. p. 207-219.

- , Rantamäki, P. \& Rokka, T. 1997. Functionality of bovine colostral whey protein hydrolysates. In: Abstracts of the 1997 International conference on food science and technology, Las Vegas, U.S.A. p. 19.

- Syvăoja, E.-L., Ahola-Luttila, H., Sivelä, S., Kopola, S., Husu, J. \& Kosunen, T. 1994. Helicobacter pylori-specific antibodies and bactericidal activity in serum, colostrum and milk of immunized and nonimmunized cows. Proceedings of the IDF seminar "Indigenous antimicrobial agents of milk - Recent developments". IDF Special Issue 9404: 151-163.

Krochta, J.M., Baldwin, E.A. \& Nisperos-Carriedo, M.O. 1994. Edible coatings and films to improve food quality. Technomic Publishing Company, Inc, Lancaster. $379 \mathrm{p}$.

Loimaranta, V., Carlén, A., Olsson, J., Suhonen, J., Korhonen, H. \& Tenovuo, J. 1996. Inhibition of adherence of Streptococcus mutans IB by bovine immune colostrum. Journal of Dental Research 75: 43.

- , Tenovuo, J., Virtanen, S., Marnila, P., Syväoja, E.-L., Tupasela, T. \& Korhonen, H. 1997. Generation of bovine immune colostrum against Streptococcus mutans and Streptococcus sobrinus and its effect on glucose uptake and extracellular polysaccharide formation by mutans streptococci. Vaccine 15, 11: 12611268

Mangino, M.E. 1992. Properties of whey protein concentrates. In: Zadow, J.G. (ed.). Whey and lactose processing. Elsevier Applied Science. p. 231-270.

Marshall, K.R. 1982. Industrial isolation of milk proteins: Whey proteins. In: Fox, P.F. (ed.). Developments in dairy chemistry-1. Applied Science Publishers, London, New York. p. 339-373.

- \& Harper, W.J. 1988. Whey protein concentrates. Bulletin of the IDF 233: 21-32.

Maté, J.I., Frankel, E.N. \& Krochta, J.M. 1996. Whey protein isolate edible coatings: Effect on the rancidity process of dry roasted peanuts. Journal of Agricultural Food Chemistry 44: 1736-1740.

Maubois, J.L. \& Ollivier, G. 1997. Extraction of milk proteins. In: Damodaran, S. \& Paraf, A. (eds.). Food proteins and their applications. Marcel Dekker Inc., New York. p. 579-595.

- , Pierre, A., Fauquant, J. \& Piot, M. 1987. Industrial fractionation of main whey proteins. Bulletin of the IDF 212: 154-159.

McHugh, T.H. \& Krochta, J.M. 1994. Sorbitol- vs glycerol-plasticized whey protein edible films: Integrated 


\title{
AGRICULTURAL AND FOOD SCIENCE IN FINLAND
}

\author{
Seminar in honour of the 100th anniversary of MTT
}

oxygen permeability and tensile property evaluation. Journal of Agricultural and Food Chemistry 42: 841845.

McIntosh, G. H., Regester, G.O., Le Leu, R.K., Royle, P.J. \& Smithers, G.W. 1995. Dairy proteins protect against dimethylhydrazine-induced intestinal cancers in rats. Journal of Nutrition 125: 809-816.

Mee, J.F. \& Mehra, R. 1995. Efficacy of colostrum substitutes and supplements in farm animals. Agro-FoodIndustry Hi- Tech- 6, 3: 31-35.

Meisel, H. 1997. Biochemical properties of regulatory peptides derived from milk proteins. Biopoly 43: 119128.

- \& Schlimme, E. 1994. Inhibitors of angiotensin converting enzyme derived from bovine casein (casokinins). In: Brantl, V. \& Teschemacher, H. (eds.) $\beta$-casomorphins and related peptides: Recent developments. VCH, Weinheim, New York. p. 27-33.

- \& Schlimme, E. 1996. Bioactive peptides derived from milk proteins: ingredients for functional foods. Kieler Milchwirtschaftliche Forschungsberichte 48, 4: 343357.

Mietens, C, Kleinhorst, H., Hilpert, H., Gerber, H., Amster, H. \& Pahud, J.J. 1979. Treatment of infantile $E$. coli gastroenteritis with specific bovine anti- $E$. coli milk immunoglobulins. European Journal of Pediatrics 132: 239-252.

Moon, H.W. \& Bunn, T.O. 1993. Vaccines for preventing enterotoxigenic Escherichia coli infections in farm animals. Vaccine 11: 213-220.

Morr, C.V. 1989. Whey proteins: Manufacture. In: Fox, P.F. (ed.) Developments in dairy chemistry -4, Elsevier Science Publishers. p. 245-284.

- 1992. Whey utilization. In: Zadow, J.G. (ed.). Whey and lactose processing. Elsevier Applied Science. p. 133-155.

- \& Ha, E.Y.W. 1993. Whey protein concentrates and isolates: processing and functional properties. Critical Reviews in Food Science and Nutrition 33: 431476.

Mullally, M.M., Meisel, H. \& FitzGerald, R.J. 1996. Synthetic peptides corresponding to $\alpha$ - lactalbumin and $\beta$-lactoglobulin sequences with angiotensin-I-converting enzyme inhibitory activity. Biological Chemistry Hoppe-Seyler 377: 259-260.

- , Meisel, H. \& FitzGerald, R.J. 1997. Identification of a novel angiotensin-l-converting enzyme inhibitory peptide corresponding to a tryptic fragment of bovine $\beta$-lactoglobulin. FEBS letters 402: 99-101.

Mulvihill, D.M. 1992. Production, functional properties and utilization of milk protein products. In: Fox, P.F. (ed.). Advanced dairy chemistry, Volume 1, Proteins. Elsevier Applied Science. p. 369-404.

- \& Fox, P.F. 1987. Assessment of the functional properties of milk protein products. Bulletin of the IDF209: 3-11.

- \& Fox, P.F. 1989. Physico-chemical and functional properties of milk proteins. In: Fox, P.F. (ed.). Developments in dairy chemistry - 4. Elsevier Science Publishers, London. p. 131-172.

- \& Fox, P.F. 1994. Developments in the production of milk proteins. In: Hudson, B.J.F. (ed.). New and de- veloping sources of food proteins. Chapman \& Hall. p. $1-30$.

Myllärinen, P., Rantamăki, P., Latva-Koivisto, J. \& Ahvenainen, R. 1997. Elintarvikepakkausten minimointi aktiivisilla syötävillä päällysteillä. Mahdollisuudet ja haasteet. VTT tiedotteita no. 1840, Espoo, Finland. $68 \mathrm{p}$.

Nakai, S. \& Li-Chan, E. 1989. Chemical and enzymatic modification of milk proteins. In: Fox, P.F. (ed.). Developments in dairy chemistry. Elsevier Science Publishers. p. 347-376.

Nord, J., Ma, P., Di John, D., Tzipori, S. \& Tacket, C. 1990. Treatment with bovine hyperimmune colostrum of cryptosporidial diarrhea in AIDS patients. AIDS 4: 581-584.

Nousiainen, J., Korhonen, H., Syvăoja, E.-L., Savolainen, S., Saloniemi, H. \& Jalonen, H. 1994. The effect of colostral immunoglobulin supplement on the passive immunity, growth and health of neonatal calves. Agricultural Science in Finland 3: 421-428.

O'Carroll, P. 1997. Nutritional beverages. The World of Ingredients, August 1997: 19-22.

O'Neill, T. \& Kinsella, J.E. 1987. Binding of alkanone flavors to $\beta$-lactoglobulin: Effects of conformational and chemical modification. Journal of Agricultural Food Chemistry 35: 770-774,

Oona, M., Răgö, T., Maaroos, H.-I., Mikelsaar, M., Loivukene, K., Salminen, S. \& Korhonen, H. 1997. Helicobacter pylori in children with addominal complaints: Has immune bovine colostrum some influence on gastritis? Alpe Adria Microbiology Journal 6: 49-57.

Outinen, M., Tossavainen, O., Syvảoja, E.-L. \& Korhonen, $H$. 1995. Chromatographic isolation of $\mathrm{K}$-casein macropeptide from cheese whey with a strong basic anion exchange resin. Milchwissenschaft 50, 10: 570-574.

-, Tossavainen, O., Tupasela, T., Koskela, P., Koskinen, H., Rantamăki, P., Syväoja, E.-L., Antila, P. \& Kankare, V. 1996. Fractionation of proteins from whey with different pilot scale processes. LebensmittelWissenschaft und Technologie 29, 5/6: 411-417.

Paakkari, I., Järvinen, A., Antila, P., Mattila, M.J. \& Pihlanto-Leppälä, A. 1994. Opioid effects of the milk whey-protein derived peptides $\alpha$ - and $\beta$-lactorphin. In: Brantl, V. \& Teschemacher, H. (eds.) $\beta$-Casomorphins and related peptides. Recent developments. VCH, Weinheim, New York. p. 33-37.

Pakkanen, R. \& Aalto, J. 1997. Growth factors and antimicrobial factors of bovine colostrum. International Dairy Journal 7: 285-297.

Parodi, P.W. 1998. A role for milk proteins in cancer prevention. Australian Journal of Dairy Technology 53: 37-47.

Paulsson, M., Hegg, P.-O. \& Castberg, H.B. 1986. Heatinduced gelation of individual whey proteins. A dynamic rheological study. Journal of Food Science 51: 87-90.

Pearce, R.J. 1983. Thermal separation of $\beta$-lactoglobulin and $\alpha$-lactalbumin in bovine cheddar cheese whey. Australian Journal of Dairy Technology 38: 144-148.

- 1992. Whey protein recovery and whey protein fractionation. In: Zadow, J.G. (ed.). Whey and lactose 
Vol. 7 (1998): 283-296.

processing. Elsevier Applied Science p. 271-316.

Pihlanto-Leppälä, A., Koskinen, P., Paakkari, I., Tupasela, T. \& Korhonen, H. 1996. Opioid whey protein peptides obtained by membrane filtration. Bulletin of the IDF 311: 36-38.

-, Paakkari, I., Rinta-Koski, M. \& Antila, P. 1997. Bioactive peptide derived from in vitro proteolysis of bovine $\beta$-lactoglobulin and its effect on smooth muscle. Journal of Dairy Research 64: 149-155.

- , Rokka, T. \& Korhonen, H. 1998. Angiotensin I converting enzyme inhibitory peptides derived from bovine milk proteins. International Dairy Journal (in press).

Plettenberg, A., Stoer, H.-J., Stellbrink, H.A. \& Meigel, W. 1993. A preparation from bovine colostrum in the treatment of HIV-positive patients with chronic diarrhea. Clinical Investigations 71: 42-45.

Reddy, N.R., Roth, S.M., Eigel, W.N. \& Pierson, M.D. 1988. Foods and food ingredients for prevention of diarrheal disease in children in developing countries. Journal of Food Protection 51: 66-75.

Regester, G.O., Mclntosh, G.H., Lee, V.W.K. \& Smithers, G.W. 1996. Whey proteins as nutritional and functional food ingredients. Food Australia 48: 123127.

- , Smithers, G.W., Mitchell, I.R., McIntosh, G.H. \& Dionysius, D.A. 1997. In: Welch, R.A.S. et al. (eds.). Milk composition, production and biotechnology. Cab International, Wallingford, UK. p. 119-132.

Rehnberg-Laiho, L., Marnila, P., Kosunen, T.U., Syvåoja, E.-L., Hănninen, M.-L., Kärkkăinen, P., Rautelin, H., Virtanen, S., Lilius, E.-M. \& Korhonen, H. 1995. Specific immune colostrum in the prevention of Helicobacter felis infection in mice. Gut 37, Suppl. 1: 368.

Reiter, B. 1985. Protective proteins in milk-biological significance and exploitation. Bulletin of the IDF 191: $1-35$.

Renner, E. 1992. Nutritional aspects. In: Zadow, J.G. (ed.). Whey and lactose processing. Elsevier Applied Science. p. 449-471.

Riedel, C.-L. 1994a. Molke-Rohstoff für neue Produkte. Teil I. Deutsche Milchwirtschaft 45: 174-179.

- 1994b. Molke-Rohstoff für neue Produkte. Teil II. Deutsche Milchwirtschaft 45: 230-235.

- 1994c. Molke-Rohstoff für neue Produkte. Teil III. Deutsche Milchwirtschaft 45: 278-283.

- 1995. Die Molke ein modernes Lebensmittel: Teil 1. Deutsche Milchwirtschaft 46: 1063-1069.

Rosenberg, M. 1995. Current and future applications for membrane process in the dairy industry. Trends in Food Science \& Technology 6, 1: 12-19.

Ruiz, L.P. 1994. Antibodies from milk for the prevention and treatment of diarrheal disease. Proceedings of the IDF seminar "Indigenous antimicrobial agents of milk - Recent developments". IDF Special Issue 9404: 108-121.

Saif, L.J., Redman, D.R., Smith, K.L. \& Theil, K.W. 1983. Passive immunity to bovine rotavirus in newborn calves fed colostrum supplements from immunized or nonimmunized cows. Infection and Immunity 41: 1118-1131.

Schaller, J.P., Saif, L.J., Cordle, C.T., Candler, E., Win- ship, T.R. \& Smith, K.L. 1992. Pevention of human rotavirus-induced diarrhea in gnotobiotic piglets using bovine antibody. Journal of Infectious Diseases 165: 623-630.

Shield, J., Melville, C., Novelli, V., Anderson, G., Scheimberg, I., Gibb, D. \& Milla, P. 1993. Bovine colostrum immunoglobulin concentrate for sporodiosis in AIDS. Archives of the Diseases of Childhood 69: 451-453.

Sienkiewicz, T. \& Riedel, C.-L. 1990. Whey and whey utilization. Verlag Th. Mann, Gelsen- kirchen-Buer, Germany. 379 p.

Smithers, G.W., Ballard, F.J., Copeland, A.D., De Silva, K.J., Dionysius, D.A., Francis, G.L., Goddard, C., Grieve, P.A., Mclntosh, G.H., Mitchell, I.R., Pearce, R.J. \& Regester, G.O. 1996. New opportunities from the isolation and utilization of whey proteins. Journal of Dairy Science 79: 1454-1459.

Stadhouders, J. \& Beumer, R.R. 1994. Actual and potential applications of the natural antimicrobial agents of milk in the dairy Industry. Proceedings of the IDF seminar "Indigenous antimicrobial agents of milk Recent developments". IDF Special Issue 9404: 175197.

Stott, G.H., Fleenor, W.A. \& Kleese, W.C. 1981. Colostral immunoglobulin in two fractions of first milking postpartum and five additional milkings. Journal of Dairy Science 64: 459-465.

Syvãoja, E.-L., Ahola-Luttila, H.K., Kalsta, H., Matilainen, M.H., Laakso, S., Husu, J.R. \& Kosunen, T.U. 1994. Concentration of Campylobacter-specific antibodies in the colostrum of immunized cows. Milchwissenschaft 49: 27-31.

Tacket, C.O., Binion, S.B., Bostwick, E., Losonsky, G., Roy, M.J. \& Edelman, R. 1992. Efficacy of bovine milk immunoglobulin concentrate in preventing illness after Shigella flexneri challenge. American Journal of Tropical Medicine and Hygiene 47: 276-283.

- , Losonsky, G., Link, H., Hoang, Y., Guesry, P., Hilpert, H. \& Levine, M.M. 1988. Protection by milk immunoglobulin concentrate against oral challenge with enterotoxigenic Escherichia coli. New England Journal of Medicine 318: 1240-1243.

Tani, F., Shiota, A., Chiba, H. \& Yoshikawa, M. 1994. Serorphin, an opioid peptide derived from bovine serum albumin, In: Brantl, V. \& Teschemacher, H. (eds.) $\beta$-Casomorphins and related peptides. Recent development. VCH, Weinheim, New York. p. 49-53.

Tossavainen, O., Rantamăki, P., Outinen, M., Tupasela, T. \& Koskela, P. 1998. Functional properties of the whey protein fractions made by pilot scale processes. Milchwissenschaft (in press).

Tsunemitsu, H., Shimizu, M., Hirai, T., Yonemichi, H., Kudo, T., Mori, K. \& Onoe, S. 1989. Protection against bovine rotaviruses in newborn calves by continous feeding of immune colostrum. Japanese Journal of Veterinary Science 51: 300-308.

Tupasela, T., Koskela, P., Pahkala, E. \& Kankare, V. 1997. Optimization of centrifugal separation of $\alpha$-lactalbumin and $\beta$-lactoglobulin. Agricultural and Food Science in Finland 6: 193-198.

- , Koskinen, H. \& Antila, P. 1994. Whey pretreatments before ultrafiltration. Agricultural Science in Finland 
Seminar in honour of the 100th anniversary of MTT

$$
\text { 3: } 473-479 \text {. }
$$

Turner, R.B. \& Kelsey, D.K. 1993. Passive immunization for prevention of rotavirus illness in healthy infants. Pediatric Infectious Disease Journal 12: 718-72.

Tzipori, S., Robertson, D., Cooper, D.A. \& White, L. 1987. Chronic cryptosporidial diarrhoea and hyperimmune cow colostrum. Lancet ii: 344-345.

Wade, V.N. 1994. The potential for whey proteins. Dairy Industries International 4: 29-33.

Wahn, U., Wahl, R. \& Rugo, R. 1992. Comparison of the residual allergenic activity of six different hydrolyzed protein formulas. Journal of Pediatrics 121: S80-84.

Wit, J.N. de 1989. Functional properties of whey proteins. In: Fox, P.F. (ed.) Developments in dairy chemistry 4, Elsevier Science Publishers, London. p. 285-321.

- 1998. Nutritional and functional characteristics of whey proteins in food products. Journal of Dairy Science 81: 597-608.

- , Hontelez-Backx, E. \& Adamse, M. 1988. Evaluation of functional properties of whey protein concentrates and whey protein isolates. 3. Functional properties in aqueous solution. Netherlands Milk Dairy Journal 42: 155-172.

- \& Hooydonk, A.C.M. van 1996. Structure, functions and applications of lactoperoxidase in natural antimicrobial systems. Netherlands Milk and Dairy Journal 50: 227-244.
- , Klarenbeek, G. \& Adamse, M. 1986. Evaluation of functional properties of whey protein concentrates and whey protein isolates. 2. Effects of processing history and composition. Netherlands Milk Dairy Journal 40: 41-56.

Wong, C.W. \& Watson, D.L. 1995. Immunomodulatory effects of dietary whey proteins in mice. Journal of Dairy Research 62: 359-368.

Xu, R.-J. 1998. Bioactive peptides in milk and their biological and health implications. Food Reviews International 14, 1: 1-16.

Yamauchi, K. 1992. Biologically functional proteins of milk and peptides derived from milk proteins. Bulletin of the IDF 272: 51-58.

Yoshikawa, M., Tani, F., Yoshimura, T. \& Chiba, H. 1986. Opioid peptides from milk proteins. Agricultural and Biological Chemistry 50: 2419-2421.

Zall, R.R. 1992. Sources and composition of whey and permeate. In: Zadow, J.G. (ed.). Whey and lactose processing. Elsevier Applied Science. p. 1-72.

Zadow, J.G. 1992. Lactose hydrolysis. In: Zadow, J.G. (ed.). Whey and lactose processing. Elsevier Applied Science. p. 361-408.

- (ed.). 1992. Whey and lactose processing. Elsevier Applied Science. 489 p.

\title{
SELOSTUS
}

\section{Heraproteiinit terveysvaikutteisten elintarvikkeiden kehittämisessä}

\author{
Hannu Korhonen, Anne Pihlanto-Leppälä, Pirjo Rantamäki ja Tuomo Tupasela \\ Maatalouden tutkimuskeskus
}

Juustoheran arvostus on voimakkaasti lisääntynyt viime vuosina uusien tieteellisten tutkimustulosten ja heran käsittelyteknologian kehittymisen ansiosta. Uusilla tekniikoilla pystytään eristämään ja rikastamaan heran aineosia entistä tehokkaammin. Spesifisten aineosien toiminnallisia ja biologisia erityisominaisuuksia voidaan siten tutkia paremmin ja kehittää uusia täsmällisiä käyttökohteita. Heran aineosien hy- väksikäyttämiseksi on muodostumassa oma teollisuuden ala, joka tuottaa yhdisteitä hyvin moneen tarkoitukseen. Terveysvaikutteiset elintarvikkeet, elintarvikkeiden rakenteelliset ominaisuudet ja biofarmaseuttiset yhdisteet ovat tällä hetkellä ja lähitulevaisuudessa merkittävimpiä tutkimus- ja kehityskohteita, joihin herasta saatuja yhdisteitä voidaan soveltaa. 